\title{
CALCINEURIN INHIBITOR-INDUCED RENAL ALLOGRAFT NEPHROTOXICITY
}

\author{
Karel Krejci*, Tomas Tichyb, Petr Bachledac ${ }^{\mathrm{c}}$, Josef Zadrazil ${ }^{\mathrm{a}}$ \\ a 3rd Department of Internal Medicine and Nephrology, University Hospital Olomouc, Czech Republic \\ ${ }^{b}$ Institute of Pathology, University Hospital Olomouc \\ 2nd Surgical Department and Transplant Centrum, University Hospital Olomouc \\ E-mail: karel.krejci@fnol.cz
}

Received: May 24, 2010; Accepted: November 12, 2010

Key words: Calcineurin inhibitors/Cyclosporine and tacrolimus/Renal allograft/Nephrotoxicity/Risk factors/Prevention

Background. The introduction of the calcineurin inhibitors (CI) cyclosporine and tacrolimus into immunosuppressive protocols initiated a new era in organ transplantation with excellent short-term graft survival. Nevertheless, the chronic nephrotoxicity of these drugs represents a significant adverse factor limiting their long-term use. Patients treated with a $\mathrm{CI}$ can be at risk for developing renal failure and this problem is especially pronounced in patients after renal transplantation.

Methods and Results. In a review paper we summarize the clinical aspects, histological manifestations and pitfalls of diagnostics of acute and chronic CI nephrotoxicity in patients after kidney transplantation. We look in detail at the disputed relationship between blood concentrations of cyclosporine and tacrolimus and histological manifestation of toxicity and summarize data showing that for toxic effects, local renal exposure to $\mathrm{CI}$ and their metabolites can play a more significant role than systemic exposure. We also include recent views on the pathophysiologic and molecular mechanisms underlying these changes; factors influencing local susceptibility to CI nephrotoxicity are discussed, including variability of expression and activity of P-glycoprotein and cytochrome P450. Last but not least we summarize our own experience with clinically manifest and subclinical forms of nephrotoxicity and their impact on the progression of chronic graft changes.

Conclusions. Owing to their unique effects, CI remain the cornerstone of most immunosuppressive protocols for renal transplantation. Together with optimization of local kidney exposure to $\mathrm{CI}$ and their metabolites, efforts to reduce systemic levels as much as possible are the most important preventive measure for reducing toxic renal graft damage.

\section{INTRODUCTION}

The introduction of the calcineurin inhibitors (CI), cyclosporine and tacrolimus into immunosuppressive protocols for renal transplantation at the end of the eighties and middle of the nineties led to a significant breakthrough in transplant medicine and the achievement of excellent short-term survival of renal grafts ${ }^{1}$. Tacrolimus was then successfully used in liver, pancreas, and heart transplantation $^{2}$. Today, both CIs are pivotal in the prevention of

\footnotetext{
ABBREVIATIONS

CI - Calcineurin inhibitors

NFAT - Nuclear factor of activated T cells

RAS - Renin-angiotensin system

NO - Nitric oxide

COX-2 - Cyclogenoxygenase-2

TGF- $\beta$ - Transforming growth factor beta

$\mathrm{C}_{0} \quad-$ Trough level of CI

$\mathrm{C}_{2} \quad$ - 2-hour CI post-dose level

$\mathrm{AUC}_{0 \text { to } 12}-$ Area under the time-concentration curve

ABCB1 - ATP-binding cassette sub-family B member 1

MDR1 - Multidrug resistance protein-1

NSAIDs - Non-steroidal anti-inflammatory drugs

ACE - Angiotensin-converting enzyme
}

allograft rejection ${ }^{3}$ and are part of more than $90 \%$ of immunosuppressive protocols used in organ transplantation $^{4}$.

Cyclosporine and tacrolimus differ in their molecular structure and intracellular binding characteristics. Cyclosporine binds to a group of cyclophilin molecules which have high affinity for calcineurin, a key protein phosphatase in the process of T-cell activation. Tacrolimus forms a complex with its cytosol partner FK506-binding protein 12 which also binds to calcineurin. By blocking calcineurin, both CIs inhibit phosphatase controlled translocation of nuclear factor of activated T cells (NFAT) into the nucleus and prevent induction of cytokines and their receptors, required for activation and proliferation of lymphocytes and other immune cells $s^{5}$.

Inhibition of the calcineurin-NFAT pathway by cyclosporine and tacrolimus is not specific to immune cells and it can lead to toxic changes in addition to immunosuppressive effects ${ }^{6}$. After kidney transplantation these can manifest as acute or chronic nephrotoxicity. For the acute form, a hemodynamically induced, usually fully reversible disorder of renal function is characteristic. The chronic nephrotoxic effects of CI are already associated with irreversible changes in the form of interstitial fibrosis and tubular atrophy ${ }^{7}$ and are considered to be a significant cause of late dysfunction of transplanted kidneys. An important measure in the prevention of these chronic 
changes is the effort to reduce the CI dose as much as possible and carefully monitor plasma levels. A pitfall in CI use is their variable pharmacokinetics, narrow therapeutic range, and individual susceptibility to their toxic effects ${ }^{8}$. CI serum levels therefore often fail to correlate with the extent of kidney damage and manifestation of toxicity can be non-specific or, especially in the first months after the transplantation, the toxic changes can be clinically silent. Significant side effects associated with cyclosporine and tacrolimus therapy not only impair long-term renal graft function but also the survival of patients. They are also a cause of significant co-morbidity. CI nephrotoxicity can be a significant clinical problem even in non-renal organ transplantation and multiple other conditions requiring treatment with these drugs.

In this review we summarize the clinical and histological aspects of CI nephrotoxicity, together with the molecular mechanisms and risk factors associated with acute and chronic nephrotoxicity. We also review current preventive and therapeutic guidelines and include our own experience with subclinical and clinically manifest forms of CI nephrotoxicity in a group of 424 protocol biopsies of transplanted kidneys.

\section{ACUTE CI NEPHROTOXICITY}

Acute CI nephrotoxicity is characterized by hemodynamically induced renal dysfunction which is nearly always fully reversible. Most data on acute toxicity relates to cyclosporine but tacrolimus effects are believed to be similar. The basis of acute nephrotoxicity is primarily the vascular effects of both CIs but we can also see some symptoms of tubular damage and more rarely symptomatology similar to thrombotic microangiopathy - hemolyticuremic syndrome.

\section{Acute arteriolopathy}

Acute hemodynamic effects associated with cyclosporine are mediated by vasoconstriction of afferent arterioles. It has been demonstrated that vasoconstriction is induced by activation of the renin-angiotensin system (RAS) and increase in levels of the vasoconstricting factors, endothelin and thromboxane, as well as suppression of synthesis of vasodilating prostacyclin, prostaglandin $\mathrm{E} 2$, and nitric oxide (NO) $)^{9-11}$. Interindividual susceptibility to cyclosporine-induced vasoconstriction also plays an important role ${ }^{12}$. RAS is activated by direct effect of cyclosporine on juxtaglomerular cells ${ }^{13}$ and indirectly by induced renal arteriolar vasoconstriction, decrease in vasodilating factors levels and increase in endothelin levels ${ }^{14}$. Renin-producing cells in afferent arterioles have also been observed in relationship to cyclosporine administration ${ }^{15}$. Activation of RAS further intensifies the hemodynamic changes by increasing the production of angiotensin II. Cyclosporine also increases free radica ${ }^{16}$ and superoxide ${ }^{17}$ production and this reduces the bioavailability of $\mathrm{NO}^{18}$. Another mechanism by which $\mathrm{CI}$ contributes to renal vasoconstriction is a shift of the balance between vasomotor effects of arachidonic acid metabolites (eicosanoids) to- wards a more pro-vasoconstriction state. The promoter for the COX-2 gene coding for cyclogenoxygenase- 2 contains binding sites for NFAT and NFAT is considered to be the main COX-2 in vitro expression stimulator ${ }^{19}$. Inhibition of calcineurin/NFAT activity thus reduces COX-2 expression ${ }^{20}$ which leads to reduction of prostaglandin E2 production and supports renal vasoconstriction. Selective COX-2 inhibitors have similar effects on renal hemodynamics to $\mathrm{CI}$.

\section{Toxic tubulopathy}

Acute CI nephrotoxicity is frequently accompanied by isometric vacuolization of tubular cytoplasm induced by enlargement of endoplasmic reticulum and multiplication of lysosomes ${ }^{21,22}$. Vacuolization can be a result of relative ischemia caused by vasoconstriction, however the possibility of damage to structure and function of endoplasmic reticulum by inhibition of calcineurin in tubular epithelial cells cannot be ruled out. In this context, it has been demonstrated that cyclosporine induces endoplasmic reticulum stress and cell damage to tubular (and endothelial) cells which can contribute to dedifferentiation and cell death $^{23-25}$ by induction of pro-apoptotic proteins ${ }^{26}$. Similar effect on tubular cells was observed with tacrolimus ${ }^{27}$. Isometric vacuolization is however not a specific finding for CI toxicity, it is also observed in patients on maintenance immunosuppression based on steroids and azathioprine, as well as in purely ischemic damage to the kidney. We also see it in the absence of renal dysfunction and it is probably not related to progression of chronic CI nephrotoxicity ${ }^{28}$.

\section{Thrombotic microangiopathy - hemolytic-uremic syndrome}

Administration of cyclosporine, and less often tacrolimus, represents an important risk factor for development of post-transplant thrombotic microangiopathy - hemolytic-uremic syndrome, a severe but fortunately infrequent form of vasculopathy. The main causative mechanism is endothelial damage due to ischemia caused by vasoconstriction; CI induced hyper-aggregation of platelets can also contribute as activation of prothrombotic factors ${ }^{29,30}$. Withdrawal of cyclosporine with conversion to tacrolimus or administration of sirolimus is usually a sufficient therapeutic measure ${ }^{31,32}$. In more severe cases, plasmapheresis, administration of intravenous immunoglobulins may be necessary and recently the positive effect of belatacept as a suitable maintenance immunosuppression in these patients has been reported ${ }^{33}$.

\section{CHRONIC CI NEPHROTOXICITY}

CI can cause both reversible change in renal hemodynamics and over the long-term lead to development of irreversible damage to parenchyma structures. Typical chronic morphological changes are arteriolar hyalinosis, tubular atrophy, interstitial fibrosis, thickening and fibrosis of the Bowman's capsule, and focal, segmental or global glomerular sclerosis ${ }^{34,35}$. The etiology of these changes most likely involves a combination of CI induced 
hemodynamic changes and direct toxic effect on tubular epithelial cells.

\section{Chronic arteriolopathy}

A characteristic sign of chronic CI toxicity is the presence of focal or circular lumpy hyaline deposits in the media of afferent arterioles (arteriolar hyalinosis) which replaces necrotic smooth muscle cells. The cause of this cellular damage is unclear, but again can be related to the important role of calcineurin-NFAT in smooth muscle cells ${ }^{36}$. If the formed deposits are large, they can cause hemodynamically significant narrowing of vascular lumen with subsequent ischemization of renal tissue ${ }^{37}$. Arteriolar hyalinosis is usually considered to be irreversible, but complete regression of severe cyclosporine-induced arteriolopathy has been reported after withdrawal of or reduction in cyclosporine dose $\mathrm{e}^{38}$.

\section{Chronic tubulo-interstitial changes}

Arteriolopathy and narrowing of arteriolar lumen can also be considered as a major contributor to the development of interstitial fibrosis (typically striped) and tubular atrophy in CI therapy. Free radicals and reactive oxygen species are produced because of local ischemia inducing cell apoptosis ${ }^{16,39}$ with damage to tubulo-interstitial cell structures. A significant etiologic factor involved in progression of chronic interstitial changes is also the CI induced increase in production of TGF- $\beta$ (transforming growth factor beta). This seems to be stimulated in part by decrease in NO release ${ }^{40}$ and in part by increase of local angiotensin II concentration ${ }^{41}$. TGF- $\beta$ supports development of interstitial fibrosis by inhibiting degradation and supporting production of proteins of the extracellular matrix and by induction of epithelial mesenchymal transition $^{42,43}$. It is also involved in progression of chronic graft vasculopathy ${ }^{44}$. The role of TGF- $\beta$ in the pathogenesis of chronic changes is supported by the fact that blocking its effect via anti-TGF- $\beta$ antibodies, led to an amelioration of morphologic manifestations of nephrotoxicity and stabilization of renal function in a mice model ${ }^{45}$. Activation of RAS also contributes to the progression of chronic tubulo-interstitial changes. Besides its direct hemodynamic effect, it stimulates secretion of aldosterone which itself worsens interstitial fibrosis by increased production of growth factors (e.g. TGF- $\beta$ ) and reactive oxygen species and by inhibition of extracellular matrix degradation ${ }^{46}$.

\section{Chronic glomerular changes}

Chronic glomerular damage associated with CI treatment occurs as a result of glomerular ischemia due to severe arteriolar hyalinosis ${ }^{47}$. Global glomerular sclerosis is most common ${ }^{48}$ but we can also see focal segmental fibrous changes caused by hyperfiltration of residual glomeruli ${ }^{49}$. Eventually, atubular glomeruli can be detected in case of tubular disruption.

\section{ELECTROLYTE DISORDERS}

Disorders of ion homeostasis, such as hyperkalemia, hypomagnesemia, hyperuricemia, and hyperchloremic metabolic acidosis often occur as a result of impaired tubular function ${ }^{50}$. Hyperkalemia in calcineurin blockade relates in part to inhibitory effects on $\mathrm{Na}^{+}-\mathrm{K}^{+}$ATPase in collecting ducts ${ }^{51,52}$ and to the decreased number of mineralocorticoid receptors ${ }^{53}$ and distal tubular acidosis. Cyclosporine also has a significant effect on magnesium metabolism. Decrease in magnesium re-absorption due to reduction of paracellin-1 expression in the thick ascending limb cells of the loop of Henlé often leads to severe hypomagnesemia ${ }^{54,55}$ which in itself facilitates development of chronic interstitial fibrosis ${ }^{56}$. Cyclosporine is also one of the leading causes of post-transplant hyperuricemia due to its inhibitory effect on tubular secretion of uric acid ${ }^{57}$.

\section{NEPHROTOXICITY DIAGNOSTIC OPTIONS}

The diagnosis of clinically manifest form of acute CI nephrotoxicity relies on correct evaluation of the clinical picture. It should be considered in the case of acute impairment of graft function by at least $20 \%$ above baseline values with concurrent elevation of cyclosporine levels $>400 \mathrm{ng} / \mathrm{ml}$ or tacrolimus $>20 \mathrm{ng} / \mathrm{ml}$. Reduction of the dose and normalization of CI levels in such a case should be followed by improvement of graft function. In the case of subclinical acute toxicity in grafts with very good function, the only option for detection is a protocol biopsy of the transplanted kidney. Biopsy represents an essential means for determining chronic nephrotoxicity and at the same time provides important information about the degree of irreversible changes of individual parenchyma structures.

Unfortunately, no other non-invasive procedure or sufficiently sensitive and specific marker is currently available for early diagnosis and monitoring of toxicity. In the early post-transplantation period, serum creatinine level does not reflect the degree of damage to the graft well ${ }^{7}$. Likewise, the increased count of CD 146+ circulating endothelial cells in peripheral blood is not specific as a marker of vascular toxic damage to the graft $^{58,59}$. In our pilot study which prospectively monitored histological and ultrasound findings of very well functioning grafts affected by subclinical rejection ${ }^{60}$, no sufficiently sensitive and specific parameter for toxicity was identified (unpublished data).

\section{COMPARISON OF TOXIC EFFECTS OF BOTH CI}

Owing to their identical mechanism of action associated with inhibition of calcineurin, both CIs have similar nephrotoxic characteristics and induce similar histological damage ${ }^{61}$. There is some evidence that tacrolimus has a lower nephrotoxic potential than cyclosporine, especially for lower vasoconstricting properties ${ }^{62}$ and profibrogenic characteristics $^{63}$; latter data however confirm similar 
effects of both CIs on the development of histological toxic changes ${ }^{48}$, progression of chronic interstitial alterations $^{64,65}$, and level of oxidative stress ${ }^{66,67}$.

In renal transplantation, the precise analysis of longterm results of graft survival based on comparison of the toxic effects of cyclosporine and tacrolimus is much more difficult to perform, because of the interference with graft rejection. The preference of tacrolimus to cyclosporine in current immunosuppressive protocols is based, despite similar nephrotoxic profile, on its more favorable metabolic profile, better anti-rejection effects, and better long-term function and survival of the graft ${ }^{68,69}$. A similar conclusion was reached by the SYMPHONY study, currently the largest randomized multicenter study comparing different immunosuppressive protocols, which showed the benefit of low dose tacrolimus over cyclosporine in terms of both long-term graft function and graft survival ${ }^{70}$.

There are also differences in the non-renal toxic effects of cyclosporine versus tacrolimus ${ }^{71}$ which often influence the choice of $\mathrm{CI}$ in a particular patient. Post-transplant diabetes mellitus, neurotoxicity, cephalea, diarrhea, and hypomagnesemia were observed more commonly after tacrolimus treatment. Cyclosporine is associated especially with gingival hyperplasia, hirsutism, higher LDL cholesterol and triglycerides levels ${ }^{68,72}$. The causes of these differences between cyclosporine and tacrolimus are not clear.

\section{FACTORS INFLUENCING DEVELOPMENT OF CI NEPHROTOXICITY}

The main goal of immunosuppressive therapy after kidney transplantation is to prevent rejection complications and at the same time toxic effects of the medication used. This is mainly achieved by monitoring blood concentrations. However, to maintain cyclosporine and tacrolimus concentrations in the recommended range is complicated by their much varied individual absorption, distribution, metabolism and elimination. For these reasons there is a poor correlation between the CI dose and subsequent blood concentration ${ }^{73}$.

\section{Therapeutic drug monitoring of CI}

Cyclosporine and tacrolimus blood levels are routinely established as fasting levels 12 hours following prior application $\left(\mathrm{C}_{0}\right)$. For tacrolimus, this analysis is considered sufficient for checking the adequacy of dosing ${ }^{74}$. However, for cyclosporine, the correlation between $\mathrm{C}_{0}$ levels and the total exposure measured as area under the time-concentration curve $\left(\mathrm{AUC}_{0 \text { to } 12}\right)$ is relatively poor. Measurement of cyclosporine levels two hours after administration $\left(\mathrm{C}_{2}\right)$ correlates more closely with exposure ${ }^{75,76}$ but the use of $\mathrm{C}_{2}$ in routine outpatient practice is complicated. Furthermore, there are no conclusive studies showing a significant benefit of $\mathrm{C}_{2}$ measurements compared to $\mathrm{C}_{0}$ in prevention of rejection or toxicity and no recommended target values for $\mathrm{C}_{2}$ have been set.

It is therefore difficult to infer CI nephrotoxicity from $\mathrm{C}_{0}$ or $\mathrm{C}_{2}$ levels. In our group of 424 protocol biopsies in which clinically manifest and subclinical nephrotoxic changes were evaluated over a one-year follow-up, $\mathrm{C}_{0}$ levels of cyclosporine and tacrolimus did not differ significantly between groups with toxicity and normal histological finding. Moreower, cyclosporine $\mathrm{C}_{2}$ levels ranging within the selected therapeutic limits did not prevent the development of toxic changes, either ${ }^{77}$. Rowshani et al. also demonstrated that even with low target AUC in month 6 and year 1 after the transplantation there is significant fibrogenic potential ${ }^{65}$, which suggests that neither such detailed monitoring approach cannon eliminate interindividual differences in sensitivity to CI, probably genetically induced.

\section{Pharmacokinetics and pharmacogenetics of CI}

Genetic variability affecting expression and function of metabolizing isoenzymes of cytochrome P450 (especially CYP3A4 and CYP3A5) and transport P-glycoprotein which is associated with single-nucleotide polymorphisms of coding genes is responsible for interindividual differences in intestinal absorption, bioavailability, and anti-rejection and toxic effects of cyclosporine and tacrolimus $^{78,79}$. Following intestinal absorption, more than $90 \%$ of cyclosporine and tacrolimus is bound to plasma proteins; in full blood both are highly concentrated in erythrocytes. Metabolic processing of CI by hydroxylation and demethylation by CYP3A4, CYP3A5 (as well as CYPP3A7) takes place mostly in the liver and gastrointestinal tract. Only small amounts of the maternal compound appear in urine and stool, most metabolites are then eliminated in bile and to some extent also in urine.

The effect of single-nucleotide polymorphism of genes for CYP3A and P-glycoprotein on CI pharmacokinetics still remains unclear. According to some authors, the CYP3A4*1B allele which increases expression of CYP3A4 is associated with significantly higher clearance of cyclosporine compared to homozygotes with normal (wild-type) allele CYP3A4* $1^{80,81}$. Other studies however failed to confirm this association ${ }^{82,83}$ obviously by reason of low population frequency of CYP $3 \mathrm{~A} 4 * 1 \mathrm{~B}$ allele and difficulties in acquiring adequate numbers of subjects for valid statistical analysis. In carriers of at least one wild-type CYP3A5*1 allele, cyclosporine administration was associated with significantly lower AUCs compared to CYP3A5*3 homozygotes with low CYP3A5 enzyme activity, where adequate levels of cyclosporine could be achieved with lower doses ${ }^{84-87}$. However these finding have not been confirmed by other authors again ${ }^{88-90}$. In a paper by Crettol et al. the pharmacokinetics of cyclosporine were evaluated in expressors of CYP3A7. Carriers of CYP3A7*1C genotype (which was shown to be a marker of CYP3A7 expression) required 1.4 to 1.6 times higher daily doses per body weight than noncarriers during the first year after transplantation ${ }^{86}$. Concerning the influence of polymorphism in ABCB1 [ATP-binding cassette subfamily B member 1, formerly known as MDR1 (multidrug resistance protein-1)] gene for P-glycoprotein on pharmacokinetics of cyclosporine, significantly lower concentrations and AUCs were demonstrated in carriers of MDR1 1236 wild-type allele compared to homozygotes with 1246 T allele ${ }^{91}$. Another study documented significantly lower AUC and $\mathrm{C}_{2}$ levels in carriers of MDR1 $3435 \mathrm{~T}$ allele 
in examination done on day 3 after the transplantation, however this difference was not significant one month later $^{92}$. Some other large scale studies did not confirm any association between polymorphisms of MDR1 and pharmacokinetics of cyclosporine ${ }^{93,85}$.

The significance of CYP3A and ABCB1 (MDR1) polymorphisms was also studied for tacrolimus. Despite of limitations associated with low population CYP3A4*1B allele frequency, lower $\mathrm{C}_{0}$ concentrations of tacrolimus were demonstrated in its carriers in $3^{\text {rd }}$ and $12^{\text {th }}$ month after transplantation, compared to CYP3A4*1 homozygotes $^{94}$. Patients with CYP3A5*3 polymorphism and missing enzyme activity exhibited higher blood levels and required lower maintenance doses of tacrolimus compared to the CYP3A5*1 variant ${ }^{95,96,90,97}$. For MDR1 and tacrolimus pharmacokinetics, carriers of $2677 \mathrm{~T}$ or $3435 \mathrm{~T}$ alleles were found to have higher average levels of tacrolimus compared to $2677 \mathrm{G}$ homozygotes (GG) and $3435 \mathrm{C}$ homozygotes $(\mathrm{CC})^{98,99}$. This association was not confirmed by other authors ${ }^{100,101}$ and the significance of other variants of the ABCB1 (MDR1) gene for pharmacokinetics of tacrolimus is unclear ${ }^{97}$.

\section{Tissue concentrations of $C I$}

As was already mentioned, not even precise monitoring of CI levels prevents development of chronic nephrotoxicity. One of the possible reasons is the fact that local CI concentrations in the renal graft do not correspond with the systemic levels, but rather are much higher ${ }^{102,103}$. In their study, Podder et al. documented that higher local concentrations of cyclosporine significantly correlate with reduction of renal function and development of histological signs of nephrotoxicity ${ }^{104}$. Studies of tissue expression and function of P-glycoprotein further elucidated the relationship between local exposure and nephrotoxicity. This transporter is expressed on the apical membrane of tubular epithelial cells and is the main protein responsible for excretion of tacrolimus and cyclosporine ${ }^{105}$. It has been demonstrated that cyclosporine-induced up-regulation of P-glycoprotein is indirectly related to incidence of arteriolar hyalinosis, interstitial fibrosis, and periglomerular fibrosis $^{106}$. On the other hand, if the expression or function of this protein is reduced, cyclosporine may accumulate. It has been documented that single-nucleotide polymorphism of ABCB1 (MDR1) in the kidney donor associated with presence of the $\mathrm{T}$ allele at position 3435 affecting the expression and function of P-glycoprotein is associated with development of chronic cyclosporine nephrotoxicity ${ }^{107}$. Whether P-glycoprotein expression is also affected by tacrolimus is still to be shown. It will also be necessary to confirm if there is a relationship between ABCB1 (MDR1) polymorphism and local renal concentrations of $\mathrm{CI}$.

\section{Toxic effects of CI metabolites}

Studies aimed at evaluation of biologic effects of CI metabolites focus mostly on their immunosuppressive characteristics; very little is known about their toxic effects. Roby et al. have shown that blood levels of cyclosporine metabolites significantly exceed levels of the maternal drug and several of these metabolites reduced glomerular filtration rate in a rat mode $1^{108}$ and led to tubular vacuolization ${ }^{109}$. In a study done in recipients of transplanted liver, a positive association between cyclosporine metabolite levels in blood and renal dysfunction was observed $^{110}$. However, the effects of these metabolites on tubular function, expression of TGF- $\beta$, and other aspects of CI nephrotoxicity are currently unknown. The nephrotoxic potential of tacrolimus metabolites has not been studied yet, however suspicion for their toxicity is supported by the fact that recipients of kidneys who express CYP3A5 (carriers of polymorphism CYP3A $5 * 1$ ) have higher risk of development of chronic CI nephrotoxicity compared to non-expressors $(\mathrm{CYP} 3 \mathrm{~A} 5 * 3 / * 3)^{111,112}$. Our knowledge is insufficient for a final verdict as to whether cyclosporine and tacrolimus metabolites contribute to development of nephrotoxicity. Hypothesis on their toxic effects will have to be verified by controlled prospective studies with measurements of CI levels and levels of their metabolites not only in blood but also in renal tissue.

\section{Local factors increasing risk of CI toxicity}

Interindividual variability in sensitivity to CI nephrotoxicity can be influenced by local renal factors independent of systemic or renal levels of cyclosporine, tacrolimus or their metabolites. Higher susceptibility to toxic damage to the older native kidneys or kidneys from older donors is probably related to alteration of autoregulation of renal perfusion and presence of pre-existing chronic vascular changes. Such predisposed kidneys also tend to have reduced capacity for natural cellular reparation ${ }^{113}$ which is especially dangerous in CI accelerated aging of cells and formation of reactive oxygen species ${ }^{114}$.

Chronic abuse of non-steroidal anti-inflammatory drugs (NSAIDs) facilitates the progression of chronic changes by a mechanism similar to the one by which these drugs increase susceptibility to CI nephrotoxicity ${ }^{115,116}$. Some other factors also represent risk for nephrotoxicity. Polymorphism of TGF- $\beta$ in codon 10 was associated with progressive dysfunction of native kidneys in recipients of transplanted hearts treated with cyclosporine or tacrolimus ${ }^{117}$. In case of recipients of transplanted kidneys, this knowledge could help identify subjects who are more susceptible to CI nephrotoxicity because they received a graft from a carrier of this polymorphism and their immunosuppressive therapy could be adjusted accordingly. The presence of polymorphism in gene for ACE (angiotensinconverting enzyme) (DD genotype) is also reported to be associated with shorter long-term graft survival in high-risk recipients of transplanted kidneys due to higher susceptibility to CI nephrotoxicity ${ }^{118}$.

\section{PREVENTION AND THERAPY OF CI NEPHROTOXICITY}

\section{Complete elimination, minimization of doses or early withdrawal of $C I$}

It is likely that some recipients of transplanted kidneys could profit from immunosuppressive protocols from 
which CI would be completely eliminated or administered only at low doses. Such practice would be suitable especially in cases of kidney transplantation from older donors and in presence of risk polymorphisms of genes for TGF- $\beta$, ACE, and enzymes and proteins involved in transport and metabolism of CI, primarily CYP3A5 and ABCB1 (MDR1). Complete exclusion of CI from immunosuppressive protocols in the immediate post-transplant period will not ensure adequate prophylaxis of acute graft rejection ${ }^{119}$. However, after a period of several months from the transplantation, the optimal choice for such high-risk patients could be conversion from a CI to less nephrotoxic drugs ${ }^{120}$ or alternatively minimization of $\mathrm{CI}$ doses with maintenance of concentrations at the lower end of the therapeutic range. Repeated protocol biopsies of the graft can be used to confirm the safety of such methods from the aspect of subclinical rejection changes or persisting subclinical toxic changes; biopsy is currently the only reliable method for monitoring the adequacy of immunosuppressive therapy. In a paper published earlier we presented our recommendation for management of CI therapy and optimal schedule of protocol biopsies of transplanted kidneys ${ }^{77}$.

\section{Alternative options}

In a situation when presence of CI in the immunosuppressive protocol is required to ensure optimal transplant results, certain preventative measures can be used to limit their nephrotoxic effects. Administration of calcium antagonists as vasodilators removes the renal vasoconstriction which, it would appear, plays a key role in development of acute and chronic toxicity. Beneficial effects of calcium antagonists on preservation of plasma flow and glomerular filtration rate in transplanted kidneys were demonstrated for nitredipine, lacidipine ${ }^{121,122}$ and nifedipine ${ }^{123}$.

In a single study, inhibition of RAS by ACE inhibitors has limited development of cyclosporine nephrotoxicity ${ }^{124}$ and administration of angiotensin II blockers led to a significant reduction in plasma levels of TGF- $\beta$ and endothe$\operatorname{lin}^{125,126}$. In an experiment, application of spironolactone eliminated many of the RAS- and aldosterone-induced effects occurring during CI therapy ${ }^{11}$; studies confirming these finding in humans are however not available.

Other therapeutic approaches are promising for the prevention of CI nephrotoxicity and progression of chronic changes, e.g. magnesium supplementation in $\mathrm{CI}$ induced hypomagnesemia ${ }^{127}$, administration of statins ${ }^{128}$ and antioxidants ${ }^{129-132}$ or application of an anti-TGF- $\beta$ antibodies ${ }^{45}$. However, no controlled studies with these approaches are available.

\section{CONCLUSION}

Introduction of cyclosporine and tacrolimus into immunosuppressive protocols significantly improved short term results of organ transplantations. However, the chronic nephrotoxicity of these agents negatively affects renal graft survival, limiting their long-term administra- tion. Pathophysiologic mechanisms behind CI nephrotoxicity are only partially elucidated and especially the question of whether inhibition of calcineurin-NFAT pathway is the main effect responsible for toxicity still remains unsolved. For the differences in interindividual sensitivity to CI, local renal factors are probably more important than systemic exposure to cyclosporine or tacrolimus. It is primarily the variability in expression and activity of P-glycoprotein and CYP3A4/5, effect of polymorphisms in genes for TGF- $\beta$ and ACE, but the autoregulation and reparation potential of the donor kidney also plays a role just as other factors facilitating toxicity, such as salt depletion and high-risk concomitant pharmacotherapy. Since CI remain, despite their nephrotoxic effect, the mainstay of immunosuppressive protocols, their use needs to be optimized. The main measure to prevent nephrotoxicity is the effort to reduce systemic levels and keep local renal exposure to CI and their metabolites as low as possible. Repeated protocol biopsy seems to be a good tool for the confirmation of the safety of such methods from the aspect of subclinical rejection changes or persisting subclinical toxicity. Currently it represents the only reliable method for checking the adequacy of immunosuppressive therapy.

\section{REFERENCES}

1. Calne RY, White DJ, Thiru S, Evans DB, McMaster P, Dunn DC, Craddock GN, Pentlow BD, Rolles K. Cyclosporin A in patients receiving renal allografts from cadaver donors. Lancet 1978;2:13231327.

2. Starzl TE, Todo S, Fung J, Demetris AJ, Venkataramman R, Jain A. FK 506 for liver, kidney, and pancreas transplantation. Lancet 1989;2:1000-1004.

3. Halloran PF. Immunosuppressive drugs for kidney transplantation. N Engl J Med 2004;351:2715-2729.

4. Andreoni KA, Brayman KL, Guidinger MK, Sommers CM, Sung RS. Kidney and pancreas transplantation in the United States, 1996-2005. Am J Transplant 2007;7:1359-1375.

5. Schreiber SL, Crabtree GR. The mechanism of action of cyclosporine A and FK-506. Immunol Today 1992;12:136-142.

6. Liu EH, Siegel RM, Harlan DM, O'Shea JJ. T cell-directed therapies: Lessons learned and future prospects. Nat Immunol 2007;8:25-30.

7. Chapman JR, Nankivell BJ. Nephrotoxicity of ciclosporin A: shortterm gain, long-term pain? Nephrol Dial Transplant 2006;21:20602063.

8. Naesens M, Lerut E, Damme BV, Vanrenterghem Y, Kuypers DR. Tacrolimus exposure and evolution of renal allograft histology in the first year after transplantation. Am J Transplant 2007;7:21142123.

9. Lanese DM, Conger JD. Effects of endothelin receptor antagonist on cyclosporine-induced vasoconstriction in isolated rat renal arterioles. J Clin Invest 1993;91:2144-2149.

10. Lamas S. Cellular mechanisms of vascular injury mediated by calcineurin inhibitors. Kidney Int 2005;68:898-907.

11. Bobadilla NA, Gamba G. New insights into the pathophysiology of cyclosporine nephrotoxicity: A role of aldosterone. Am J Physiol Renal Physiol 2007;293:F2-F9.

12. Wissmann C, Frey FJ, Ferrari P, Uehlinger DE. Acute cyclosporineinduced nephrotoxicity in renal transplant recipients: The role of the transplanted kidney. J Am Soc Nephrol 1996;7:2677-2681.

13. Kurtz A, Della BR, Kuhn K. Cyclosporine A enhances renin secretion and production in isolated juxtaglomerular cells. Kidney Int 1988;33:947-953. 
14. Ruster C, Wolf G. Renin-angiotensin-aldosterone systém and progression of renal disease. J Am Soc Nephrol 2006;17:2985-2991.

15. Iijima K, Hamahira K, Kobayashi A, Nakamura H, Yoshikawa $\mathrm{N}$. Immunohistochemical analysis of renin aktivity in chronic cyclosporine nephropathy in childhood neohrotiv syndrome. J Am Soc Nephrol 2000;11:2265-2271.

16. Zhong Z, Arteel GE, Connor HD, Yin M, Frankenberg MV, Stachlewitz RF, Raleigh JA, Mason RP, Thurman RG. Cyclosporin A increases hypoxia and free radical production in rat kidneys: Prevention by dietary glycine. Am J Physiol 1988;275:F595-F604

17. Diederich D, Skopec J, Diederich A, Dai FX. Cyclosporine produces endothelial dysfunction by increased production of superoxide. Hypertension 1994;23:957-961.

18. Navarro-Antolin J, Lopez-Munoz MJ, Klatt P, Soria J, Michel T, Lamas S. Formation of peroxynitrite in vascular endothelial cells exposed to cyclosporine A. FASEB J 2001;15:1291-1293.

19. Sugimoto T, Haneda M, Sawano H, Isshiki K, Maeda S, Koya D, Inoki K, Yasuda H, Kashiwagi A, Kikkawa R. Endothelin-1 in duces cyclooxygenase-2 expression via nuclear factor of activated T-cell transcription factor in glomerular mesangial cells. J Am Soc Nephrol 2001;12:1359-1368.

20. Hocherl K, Dreher F, Vitzthum H, Kohler J, Kurtz A. Cyclosporine A suppresses cyclooxygenase-2 expression in the rat kidney. J Am Soc Nephrol 2002;13:2427-2436.

21. Mihatsch MJ, Thiel G, Basler V, Ryffel B, Landmann J, von Overbeck J, Zollinger HU. Morphological patterns in cyclosporinetreated renal transplant recipients. Transplant Proc 1985;17:101 116.

22. Morozumi K, Takeda A, Uchida K, Mihatsch MJ. Cyclosporine nephrotoxicity: how does it affect renal allograft function and transplant morphology? Transpl Proc 2004;36:S251-S256.

23. Pallet N, Rabant M, Xu-Dubois YC, Lecorre D, Mucchielli MH, Imbeaud S, Agier N, Hertig A, Thervet E, Legendre C, Beaune $\mathrm{P}$, Anglicheau D. Response of human renal tubular cells to cyclosporine and sirolimus: a toxicogenomic study. Toxicol App Pharmacol 2008;229:184-196.

24. Bouvier N, Flinois JP, Gilleron J, Sauvage FL, Legendre C, Beaune P, Thervet E, Anglicheau D, Pallet N. Cyclosporine triggers endoplasmic reticulum stress in endothelial cells: a role for endothelial phenotypic changes and death. Am J Physiol Renal Physiol 2009;296:F160-F169.

25. Pallet N, Bouvier N, Bendjallabah A, Rabant M, Flinois JP, Hertig A, Legendre C, Beaune P, Thervet E, Anglicheau D. Cyclosporineinduced endoplasmic reticulum stress triggers tubular phenotypic changes and death. Am J Transplant 2008;8:2283-2296.

26. Han SW, Li C, Ahn KO, Lim SW, Song HG, Jang YS, Cho YM, Jang YM, Ghee JY, Kim JY, Kim SH, Kim J, Kwon OJ, Yang CW. Prolonged endoplasmic reticulum stress induces apoptotic cell death in an experimental model of chronic cyclosporine nephropathy. Am J Nephrol 2008;28:707-714.

27. Du S, Hiramatsu N, Hayakawa K, Kasai A, Okamura M, Huang T, Yao J, Takeda M, Araki I, Sawada N, Paton AW, Paton JC, Kitamura M. Suppression of NF- $\mathrm{B}$ by cyclosporine A and tacrolimus (FK506) via induction of the C/EBP family: implication for unfolded protein response. J Immunol 2009;182:7201-7211.

28. Naesens M, Kambham N, Concepcion W, Salvatierra O, Jr., Sarwa $\mathrm{M}$. The evolution of non-immune histological injury and its clinical relevance in adult-sized kidney grafts in pediatric recipients. Am J Transplant 2007;7:2504-2514.

29. Franz M, Regele H, Schmaldienst S, Stummvoll HK, Horl WH, Pohanka E. Posttransplant hemolytic uremic syndrome in adult retransplanted kidney graft recipients: Advantage of FK506 therapy? Transplantation 1998;66:1258-1262.

30. Ponticelli C. De novo thrombotic microangiopathy. An underrated complication of renal transplantation. Clin Nephrol 2007;67:335340.

31. Oyen O, Strom EH, Midtvedt K, Bentdal O, Hartmann A, Bergan S, Pfeffer P, Brekke IB. Calcineurin inhibitor-free immunosuppression in renal allograft recipients with thrombotic microangiopathy/ hemolytic uremic syndrome. Am J Transplant 2006;6:412-418.

32. Bren A, Pajek J, Grego K, Buturovic J, Ponikvar R, Lindic J, Knap B, Vizjak A, Ferluga D, Kandus A. Follow-up of kidney graft recipi- ents with cyclosporine-associated hemolytic-uremic syndrome and thrombotic microangiopathy. Transplant Proc 2005;37:1889-1891.

33. Ashman N, Chapagain A, Dobbie H, Raftery MJ, Sheaff MT, Yaqoob MM. Belatacept as maintenance immunosuppression for postrenal transplant de novo drug-induced thrombotic microangiopathy. Am J Transplant 2009;9:424-427.

34. Randhawa PS, Shapiro R, Jordan ML, Starzl TE, Demetris AJ. The histopathological changes associated with allograft rejection and drug toxicity in renal transplant recipients maintained on FK506. Clinical significance and comparison with cyclosporine. Am J Surg Pathol 1993; 17:60-68

35. Williams D, Haragsim L. Calcineurin nephrotoxicity. Adv Chronic Kidney Dis 2006;13:47-55

36. Nieves-Cintron M, Amberg GC, Nichols CB, Molkentin JD, Santana LF. Activation of NFATc3 down-regulates the beta 1 subunit of large conductance, calcium-activated $\mathrm{K}+$ channels in arterial smooth muscle and contributes to hypertension. J Biol Chem 2007;282:3231-3240

37. Mihatsch MJ, Kyo M, Morozumi K, Yamaguchi Y, Nickeleit V, Ryffel B. The side-effects of ciclosporine-A and tacrolimus. Clin Nephrol 1998;49:356-363.

38. Collins BS, Davis CL, Marsh CL, McVicar JP, Perkins JD, Alpers CE. Reversible cyclosporine arteriolopathy. Transplantation 1992;54:732-734.

39. Djamali A. Oxidative stress as a common pathway to chronic tubulointerstitial injury in kidney allografts. Am J Physiol Renal Physiol 2007;293:F445-F455.

40. Shihab FS, Yi H, Bennett WM, Andoh TF. Effect of nitric oxide modulation on TGF-beta1 and matrix proteins in chronic cyclosporine nephrotoxicity. Kidney Int 2000;58:1174-1185.

41. Pichler RH, Franceschini N, Young BA, Hugo C, Andoh TF, Burdmann EA, Shankland SJ, Alpers CE, Bennett WM, Couser WG. Pathogenesis of cyclosporine nephropathy: roles of angiotensin II and osteopontin. J Am Soc Nephrol 1995;6:1186-1196.

42. Feldman G, Kiely B, Martin N, Ryan G, McMorrow T, Ryan MP. Role for TGF-beta in cyclosporine-induced modulation of renal epithelial barrier function. J Am Soc Nephrol 2007;18:1662-1671.

43. Hertig A, Anglicheau D, Verine J, Pallet N, Touzot M, Ancel PY, Mesnard L, Brousse N, Baugey E, Glotz D, Legendre C, Rondeau E, Xu-Dubois YC. Early epithelial phenotypic changes predict graft fibrosis. J Am Soc Nephrol 2008;19:1584-1591.

44. Viklický O, Matl I, Voska L, Böhmová R, Jarešová M, Lácha J, Lodererová A, Střiž I, Teplan V, Vítko S. TGF-betal expression and chronic allograft nephropathy in protocol kidney graft biopsy. Physiol Res 2003;52:353-360

45. Ling H, Li X, Jha S, Wang W, Karetskaya L, Pratt B, Ledbetter S. Therapeutic role of TGF-beta-neutralizing antibody in mouse cyclosporin A nephropathy: morphologic improvement associated with functional preservation. J Am Soc Nephrol 2003;14:377-388.

46. Remuzzi G, Cattaneo D, Perico N. The aggravating mechanisms of aldosterone on kidney fibrosis. J Am Soc Nephrol 2008;19:14591462.

47. Nankivell B, Richard J, Borrows R, Fung CL-S, O’Connell PJ, Allen R, Chapman JR. The natural history of chronic allograft nephropathy. N Engl J Med 2003;349:2326-2333.

48. Nankivell BJ, Borrows RJ, Fung C L-S, O’Connell PJ, Chapman JR, Allen RD. Calcineurin-inhibitor nephrotoxicity: Longitudinal assessment by protocol histology. Transplantation 2004;78:557565 .

49. Woolley AC, Rosenberg ME, Burke BA, Nath KA. De novo focal glomerulosclerosis after kidney transplantation. Am J Med 1988;84:310-314.

50. Heering P, Grabensee B. Influence of ciclosporin A on renal tubular function after kidney transplantation. Nephron 1991;59:66-70.

51. Lea JP, Sands JM, McMahon SJ, Tumlin JA. Evidence that the inhibition of $\mathrm{Na}+/ \mathrm{K}(+)$-ATPase activity by FK506 involves calcineurin. Kidney Int 1994;46:647-652.

52. Younes-Ibrahim M, Barnese M, Burth P, Castro-Faria MV. Inhibition of purified human kidney $\mathrm{Na}^{+}, \mathrm{K}+$-ATPase by cyclosporine A: A possible mechanism for drug human nephrotoxicity. Ann N Y Acad Sci 2003;986:633-635. 
53. Heering PJ, Klein-Vehne N, Fehsel K. Decreased mineralocorticoid receptor expression in blood cells of kidney transplant recipients undergoing immunosuppressive treatment: Cost efficient determination by quantitative PCR. J Clin Pathol 2004;57:33-36.

54. Chang CT, Hung CC, Tian YC, Yang CW, Wu MS. Ciclosporin reduces paracellin-1 expression and magnesium transport in thick ascending limb cells. Nephrol Dial Transplant 2007;22:1033-1040.

55. Alexander RT, Hoenderop JG, Bindels RJ. Molecular determinants of magnesium homeostasis: Insights from human disease. J Am Soc Nephrol 2008;19:1451-1458.

56. Miura K, Nakatani T, Asai T, Yamanaka S, Tamada S, Tashiro K, Kim S, Okamura M, Iwao H. Role of hypomagnesemia in chronic cyclosporine nephropathy. Transplantation 2002;73:340-347.

57. Clive DM. Renal transplant-associated hyperuricemia and gout. J Am Soc Nephrol 2000;11:974-979.

58. Woywodt A, Bahlmann FH, De Groot K, Haller H, Haubitz M. Circulating endothelial cells: life, death, detachment and repair of the endothelial cell layer. Nephrol Dial Transplant 2002;17:17281730 .

59. Koo DD, Roberts IS, Quiroga I, Procter J, Barnardo MC, Sutton M, Cerundolo L, Davies DR, Friend PJ, Morris PJ, Fuggle SV. C4d deposition in early renal allograft protocol biopsies. Transplantation 2004;78:398-403.

60. Krejčí K, Zadražil J, Tichý T, Al-Jabry S, Horčička V, Štrebl P, Bachleda P. Sonographic findings in borderline changes and subclinical acute renal allograft rejection. Eur J Radiol 2009;71:288295.

61. Solez K, Vincenti F, Filo R. Histopathologic findings from 2-year protocol biopsies from a US multicenter kidney transplant trial comparing tacrolimus versus ciclosporine. Transplantation 1998;66:1736-1740.

62. Klein IH, Abrahams A, van ET, Hene RJ, Koomans HA, Ligtenberg G. Different effects of tacrolimus and cyclosporine on renal hemodynamics and blood pressure in healthy subjects. Transplantation 2002;73:732-736.

63. Jain S, Bicknell G, Nicholson ML. Tacrolimus has less fibrogenic potential than cyclosporin A in a model of renal ischaemia-reperfusion injury. Br J Surg 2000;87:1563-1568.

64. O'Grady JG, Burroughs A, Hardy P, Elbourne D, Truesdale A. Tacrolimus versus microemulsified ciclosporin in liver transplantation: The TMC randomised controlled trial. Lancet 2002;360:11191125.

65. Rowshani AT, Scholten EM, Bemelman F, Eikmans M, Idu M, Roos-van Groningen MC, Surachno JS, Mallat MJ, Paul LC, de Fijter JW, Bajema IM, ten Berge I, Florquin S. No difference in degree of interstitial Sirius red-stained area in serial biopsies from area under concentration-over-time curves-guided cyclosporine versus tacrolimus-treated renal transplant recipients at one zdar. J Am Soc Nephrol 2006;17:305-312.

66. Vural A, Yilmaz MI, Caglar K, Aydin A, Sonmez A, Eyileten T, Acikel C, Gulec B, Kozak O, Oner K. Assessment of oxidative stress in the early posttransplant period: comparison of cyclosporine A and tacrolimus-based regimens. Am J Nephrol 2005; 25:250-255

67. Zadražil J, Štrebl P, Krejčí K, Horčička V, Horák P, Dostálová J, Zdařilová A, Kajabová M, Schneidera P. Effect of different calcineurin inhibitors on AOPP and TAS after kidney transplantation. Clin Biochem 2010;43:559-565

68. Webster AC, Woodroffe RC, Taylor RS, Chapman JR, Craig JC. Tacrolimus versus ciclosporin as primary immunosuppression for kidney transplant recipients: Meta-analysis and meta-regression of randomised trial data. BMJ 2005;331:810-814.

69. Zadražil J, Krejčí K, Al Jabry S, Horčička V Jr, Tichý T, Hrabalová M, Bachleda P. Protocol biopsy and subclinical rejection in patients after kidney transplantation treated by tacrolimus (Prograf) Biomed Pap Med Fac Univ Palacky Olomouc Czech Repub 2003; 147:193-196

70. Ekberg H, Tedesco-Silva H, Demirbas A, Vitko S, Nathan B, Gurkan A, Margreiter R, Hugo C, Grinyo JM, Frei U, Vanrenterghem Y, Daloze P, Halloran PF. Reduced exposure to calcineurin inhibitors in renal transplantation. N Engl J Med 2007; 357:2562-2575.

71. Zadražil J, Horák P, Zahálková J, Štrebl P, Horčička V, Krejčí K,
Bachleda P, Dědochová J, Valkovský I. Improvement of cardiovascular risk factors and cosmetic side effects in kidney transplant recipients after conversion to tacrolimus. Biomed Pap Med Fac Univ Palacky Olomouc Czech Repub 2009;153:67-73.

72. Vincenti F, Friman S, Scheuermann E, Rostaing L, Nenesen T, Campistol JM, Uchida K, Pescovitz MD, Marchetti P, Tuncer M, Citterio F, Wiecek A, Chadban S, El-Shahawy M, Budde K, Goto $\mathrm{N}$. Results of an international, randomized trial comparing glucose metabolism disorders and outcome with cyclosporine versus tacrolimus. Am J Transplant 2007;7:1506-1514.

73. Wilkinson GR. Drug metabolism and variability among patients in drug response. N Engl J Med 2005;352:2211-2221.

74. Oellerich M, Armstrong VW. The role of therapeutic drug monitoring in individualizing immunosuppressive drug therapy: Recent developments. Ther Drug Monit 2006;28:720-725.

75. Canadian Neoral Renal Transplantation Study Group: Absorption profiling of cyclosporine microemulsion (neoral) during the first 2 weeks after renal transplantation. Transplantation 2001;72:1024-1032.

76. International Neoral Renal Transplantation Study Group: Cyclosporine microemulsion (Neoral) absorption profilig and sparse-sample predictors during the first 3 months after renal transplantation. Am J Transplant 2002;2:148-156.

77. Krejčí K, Tichý T, Hrubý M, Horák P, Ciferská H, Horčička V, Štrebl P, Al-Jabry S, Bachleda P, Zadražil J. Subclinical toxicity of calcineurin inhibitors in repeated protocol biopsies: an independent risk factor for chronic kidney allograft damage. Transpl Int 2010;23:364-373.

78. Benet LZ, Izumi T, Zhang Y, Silverman JA, Wacher VJ. Intestinal MDR transport proteins and P-450 enzymes as barriers to oral drug delivery. J Control Release 1999;62:25-31.

79. Lown KS, Mayo RR, Leichtman AB, Hsiao HL, Turgeon DK, Schmiedlin-Ren P, Brown MB, Guo W, Rossi SJ, Benet LZ, Watkins PB. Role of intestinal P-glycoprotein (mdr1) in interpatient variation in the oral bioavailability of cyclosporine. Clin Pharmacol Ther 1997;62:248-260.

80. Min DI, Ellingrod VL. Association of the CYP3A4*1B 5 flanking region polymorphism with cyclosporine pharmacokinetics in healthy subjects. Ther Drug Monit 2003;25:305-309.

81. Hesselink DA, van Gelder T, van Schaik RH, Balk AH, van der Heiden IP, van Dam T, van der Werf M, Weimar W, Mathot RA. Population pharmacokinetics of cyclosporine in kidney and heart transplant recipients and the influence of ethnicity and genetic polymorphisms in theMDR-1,CYP3A4, and CYP3A5 genes. Clin Pharmacol Ther 2004;76:545-556.

82. Rivory LP, Qin H, Clarke SJ, Eris J, Duggin G, Ray E, Trent RJ, Bishop JF. Frequency of cytochrome P450 3A4 variant genotype in transplant population and lack of association with cyclosporin clearance. Eur J Clin Pharmacol 2000;56:395-398.

83. von Ahsen N, Richter M, Grupp C, Ringe B, Oellerich M, Armstrong VW. No influence of the MDR-1 C3435T polymorphism or a CYP3A4 promoter polymorphism (CYP3A4-V allele) on dose-adjusted cyclosporin A trough concentrations or rejection incidence in stable renal transplant recipients. Clin Chem 2001;47:1048-1052.

84. Min DI, Ellingrod VL, Marsh S, McLeod H. CYP3A5 polymorphism and the ethnic differences in cyclosporine pharmacokinetics in healthy subjects. Ther Drug Monit 2004;26:524-528.

85. Haufroid V, Mourad M, Van Kerckhove V, Wawrzyniak J, De Meyer M, Eddour DC, Malaise J, Lison D, Squifflet JP, Wallemacq P. The effect of CYP3A5 and MDR1 (ABCB1) polymorphisms on cyclosporine and tacrolimus dose requirements and trough blood levels in stable renal transplant patients. Pharmacogenetics 2004; 14:147-154.

86. Crettol S, Venetz JP, Fontana M, Aubert JD, Pascual M, Eap CB. CYP3A7, CYP3A5, CYP3A4, and ABCB1 genetic polymorphisms, cyclosporine concentration, and dose requirement in transplant recipients. Ther Drug Monit 2008;30:689-699.

87. Singh R, Srivastava A, Kapoor R, K Sharma R, D Mittal R. Impact of CYP3A5 and CYP3A4 gene polymorphisms on dose requirement of calcineurin inhibitors, cyclosporine and tacrolimus, in renal allograft recipients of North India. Naunyn Schmied Arch Pharmacol 2009;380:169-177. 
88. Kreutz R, Zürcher H, Kain S, Martus P, Offermann G, Beige J. The effect of variable CYP3A5 expression on cyclosporine dosing, blood pressure and long-term graft survival in renal transplant patients. Pharmacogenetics 2004;14:665-671.

89. Zhao Y, Song M, Guan D, Bi S, Meng J, Li Q, Wang W. Genetic polymorphisms of CYP3A5 genes and concentration the cyclosporine and tacrolimus. Transplant Proc 2005;37:178-181.

90. Coto E, Tavira B. Pharmacogenetics of calcineurin inhibitors in renal transplantation. Transplantation 2009;88(3 Suppl):S62-67.

91. Anglicheau D, Thervet E, Etienne I, Hurault De Ligny B, Le Meur Y, Touchard G, Büchler M, Laurent-Puig P, Tregouet D, Beaune P, Daly A, Legendre C, Marquet P. CYP3A5 and MDR1 genetic polymorphisms and cyclosporine pharmacokinetics after renal transplantation. Clin Pharmacol Ther 2004;75:422-433.

92. Foote CJ, Greer W, Kiberd B, Fraser A, Lawen J, Nashan B, Belitsky P. Polymorphisms of multidrug resistance gene (MDR1) and cyclosporine absorption in de novo renal transplant patients. Transplantation 2007;83:1380-1384.

93. Mai I, Störmer E, Goldammer M, Johne A, Krüger H, Budde K, Roots I. MDR1 haplotypes do not affect the steady-state pharmacokinetics of cyclosporine in renal transplant patients. J Clin Pharmacol 2003;43:1101-1107.

94. Hesselink DA, van Schaik RH, van der Heiden IP, van der Werf M, Gregoor PJ, Lindemans J, Weimar W, van Gelder T. Genetic polymorphisms of the CYP3A4, CYP3A5, and MDR-1 genes and pharmacokinetics of the calcineurin inhibitors cyclosporine and tacrolimus. Clin Pharmacol Ther 2003;74:245-254.

95. Op den Buijsch RA, Christiaans MH, Stolk LM, de Vries JE, Cheung CY, Undre NA, van Hooff JP, van Dieijen-Visser MP, Bekers O. Tacrolimus pharmacokinetics and pharmacogenetics: influence of adenosine triphosphate-binding cassette $\mathrm{B}$ (ABCB1) and cytochrome (CYP) 3A polymorphisms. Fundam Clin Pharmacol 2007;21:427-435.

96. Renders L, Frisman M, Ufer M, Mosyagin I, Haenisch S, Ott U, Caliebe A, Dechant M, Braun F, Kunzendorf U, Cascorbi I. CYP3A5 genotype markedly influences the pharmacokinetics of tacrolimus and sirolimus in kidney transplant recipients. Clin Pharmacol Ther 2007;81:228-234.

97. Jun KR, Lee W, Jang MS, Chun S, Song GW, Park KT, Lee SG, Han DJ, Kang C, Cho DY, Kim JQ, Min WK. Tacrolimus concentrations in relation to $\mathrm{CYP} 3 \mathrm{~A}$ and $\mathrm{ABCB} 1$ polymorphisms among solid organ transplant recipients in Korea. Transplantation 2009;87:1225-1231.

98. Akbas SH, Bilgen T, Keser I, Tuncer M, Yucetin L, Tosun O, Gultekin M, Luleci G. The effect of MDR1 (ABCB1) polymorphism on the pharmacokinetic of tacrolimus in Turkish renal transplant recipients. Transplant Proc 2006;38:1290-1292.

99. Li D, Gui R, Li J, Huang Z, Nie X. Tacrolimus dosing in Chinese renal transplant patients is related to MDR1 gene C3435T polymorphisms. Transplant Proc 2006;38:2850-2852.

100. Tsuchiya N, Satoh S, Tada H, Li Z, Ohyama C, Sato K, Suzuki T, Habuchi T, Kato T. Influence of CYP3A5 and MDR1 (ABCB1) polymorphisms on the pharmacokinetics of tacrolimus in renal transplant recipients. Transplantation 2004;78:1182-1187.

101. Tada H, Tsuchiya N, Satoh S, Kagaya H, Li Z, Sato K, Miura M, Suzuki T, Kato T, Habuchi T. Impact of CYP3A5 and MDR1 (ABCB1) C3435T polymorphisms on the pharmacokinetics of tacrolimus in renal transplant recipients. Transplant Proc 2005; 37:1730-1732.

102. Halloran PF, Helms LM, Kung L, Noujaim J. The tempoval profile of calcineurin inhibition by cyclosporine in vivo. Transplantation 1999;68:1356-1361.

103. Iwasaki K, Shiraga T, Matsuda H, Teramura Y, Kawamura A, Hata T, Ninomiya S, Esumi Y. Absorption, distribution, metabolism and excretion of tacrolimus (FK506) in the rat. Drug Metab Pharmacokinet 1998;13:259-265.

104. Podder H, Stepkowski SM, Napoli KL, Clark J, Verani RR, Chou TC, Kahan BD. Pharmacokinetic interactions augment toxicities of sirolimus/cyclosporine combinations. J Am Soc Nephrol 2001;12:1059-1071.
105. Saeki T, Ueda K, Tanigawara Y, Hori R, Komano T. Human P-glycoprotein transports cyclosporin A and FK506. J Biol Chem 1993;268:6077-6080.

106. del Moral RG, Andujar M, Ramirez C, Gomez-Morales M, Masseroli M, Aguilar M, Olmo A, Arrebola F, Guillen M, GarciaChicano MJ, Nogales FF, O'Valle F. Chronic cyklosporin A nephrotoxicity, P-glycoprotein overexpression, and relationships with intrarenal angiotensin II deposits. Am J Pathol 1997;151:17051714.

107. Hauser IA, Schaeffeler E, Gauer S, Scheuermann EH, Wegner B, Gossmann J, Ackermann H, Seidl C, Hocher B, Zanger UM, Geiger H, Eichelbaum M, Schwab M. ABCB1 genotype of the donor but not of the recipient is a major risk factor for cyclosporine-related nephrotoxicity after renal transplantation. J Am Soc Nephrol 2005;16:1501-1511.

108. Roby KA, Shaw LM. Effects of cyclosporine and its metabolites in the isolated perfused rat kidney. J Am Soc Nephrol 1993;4:168177.

109. Copeland KR, Thliveris JA, Yatscoff RW. Toxicity of cyclosporine metabolites. Ther Drug Monit 1990;12:525-532.

110. Christians U, Kohlhaw K, Budniak J, Bleck JS, Schottmann R, Schlitt HJ, Almeida VM, Deters M, Wonigeit K, Pichlmayr R. Cyclosporine metabolite pattern in blood and urine of liver graft recipients. I. Association of cyclosporine metabolites with nephrotoxicity. Eur J Clin Pharmacol 1991;41:285-290.

111. Kuehl P, Zhang J, Lin Y, Lamba J, Assem M, Schuetz J, Watkins PB, Daly A, Wrighton SA, Hall SD, Maurel P, Relling M, Brimer C, Yasuda K, Venkataramanan R, Strom S, Thummel K, Boguski MS, Schuetz E. Sequence diversity in CYP3A promoters and characterization of the genetic basis of polymorphic CYP3A5 expression. Nat Genet 2001;27:383-391.

112. Kuypers DR, de Jonge H, Naesens M, Lerut E, Verbeke K, Vanrenterghem Y. CYP3A5 and CYP3A4 but not MDR1 singlenucleotide polymorphisms determine long-term tacrolimus disposition and drug-related nephrotoxicity in renal recipients. Clin Pharmacol Ther 2007;82:711-725.

113. Schmitt R, Cantley LG. The impact of aging on kidney repair. Am J Physiol Renal Physiol 2008;294:F1265-F1272.

114. Jennings $\mathrm{P}$, Koppelstaetter C, Aydin S, Abberger T, Wolf AM, Mayer G, Pfaller W. Cyclosporine A induces senescence in renal tubular epithelial cells. Am J Physiol Renal Physiol 2007;293:F831-F838.

115. Altman RD, Perez GO, Sfakianakis GN. Interaction of cyclosporine A and nonsteroidal anti-inflammatory drugs on renal function in patients with rheumatoid arthritis. Am J Med 1992;93:396-402.

116. Soubhia RM, Mendes GE, Mendonca FZ, Baptista MA, Cipullo JP, Burdmann EA. Tacrolimus and nonsteroidal anti-inflammatory drugs: An association to be avoided. Am J Nephrol 2005;25:327334.

117. van de Wetering J, Weimar CH, Balk AH, Roodnat JI, Holweg CT, Baan CC, van Domburg RT, Weimar W. The impact of transforming growth factor-betal gene polymorphism on end-stage renal failure after heart transplantation. Transplantation 2006;82:17441748.

118. Broekroelofs J, Stegeman CA, Navis G, Tegzess AM, De ZD, De Jong PE. Risk factors for long-term renal survival after renal transplantation: A role for angiotensin-converting enzyme (insertion/ deletion) polymorphism? J Am Soc Nephrol 1998;9:2075-2081.

119. Srinivas TR, Meier-Kriesche HU. Minimizing immunosuppression, an alternative approach to reducing side effects: Objectives and interim result. Clin J Am Soc Nephrol 2008;3:S101-S116.

120. Flechner SM, Kobashigawa J, Klintmalm G. Calcineurin inhibitor-sparing regimens in solid organ transplantation: Focus on improving renal function and nephrotoxicity. Clin Transplant 2008;22:1-15.

121. Rahn KH, Barenbrock M, Fritschka E, Heinecke A, Lippert J, Schroeder K, Hauser I, Wagner K, Neumayer HH. Effect of nitrendipine on renal function in renal-transplant patiens treated with cyclosporin: A randomised trial. Lancet 1999;354:1415-1420. 
122. Kuypers DR, Neumayer H-H, Fritsche L, Budde K, Rodicio J, Vanrenterghem Y, Lacidipine Study Group. Calcium channel blockade and preservation of renal graft function in cyclosporinetreated recipients: A prospective randomized placebo-controlled 2-year study. Transplantation 2004;78:1204-1211.

123. Morales JM, Rodriguez-Paternina E, Araque A, Andres A, Hernandez E, Ruilope LM, Rodicio JL. Long-term protective effect of a calcium antagonist on renal function in hypertensive renal transplant patients on cyclosporine therapy: A 5-year prospective randomized study. Transplant Proc 1994;26:2598-2599.

124. Hannedouche TP, Natov S, Boitard C, Lacour B, Grunfeld JP. Angiotensin converting enzyme inhibition and chronic cyclosporine-induced renal dysfunction in type 1 diabetes. Nephrol Dial Transplant 1996;11:673-678.

125. Campistol JM, Inigo P, Jimenez W, Lario S, Clesca PH, Oppenheimer F, Rivera F. Losartan decreases plasma levels of TGF-beta1 in transplant patients with chronic allograft nephropathy. Kidney Int 1999;56:714-719.

126. Inigo P, Campistol JM, Lario S, Piera C, Campos B, Bescos M, Oppenheimer F, Rivera F. Effects of losartan and amlodipine on intrarenal hemodynamics and TGF-beta(1) plasma levels in a crossover trial in renal transplant recipients. J Am Soc Nephrol 2001;12:822-827.

127. Asai T, Nakatani T, Tamada S, Kuwabara N, Yamanaka S, Tashiro K, Nakao T, Komiya T, Okamura M, Kim S, Iwao H, Miura K.
Activation of transcription factors AP-1 and NF-kappaB in chronic cyclosporine A nephrotoxicity: Role in beneficial effects of magnesium supplementation. Transplantation 2003;75:1040-1044.

128. Li C, Sun BK, Lim SW, Song JC, Kang SW, Kim YS, Kang DH, Cha JH, Kim J, Yang CW. Combined effects of losartan and pravastatin on interstitial inflammation and fibrosis in chronic cyclosporine-induced nephropathy. Transplantation 2005; 79:1522-1529.

129. Tariq M, Morais C, Sobki S, Al Sulaiman M, Al Khader A. $\mathrm{N}$-acetylcysteine attenuates cyclosporin-induced nephrotoxicity in rats. Nephrol Dial Transplant 1999;14:923-929.

130. Jenkins JK, Huang H, Ndebele K, Salahudeen AK. Vitamin E inhibits renal mRNA expression of COX II, HO I, TGFbeta, and osteopontin in the rat model of cyclosporine nephrotoxicity. Transplantation 2001;71:331-334.

131. Lessio C, de Assuncao SF, Gloria MA, Di Tommaso AB, Gori MM, Di Marco GS, Schor N, Higa EM. Cyclosporine A and NAC on the inducible nitric oxide synthase expression and nitric oxide synthesis in rat renal artery cultured cells. Kidney Int 2005;68:2508-2516.

132. Galletti P, Di Gennaro CNI, Migliardi V, Indaco S, Della RF, Manna C, Chiodini P, Capasso G, Zappia V. Diverse effects of natural antioxidants on cyclosporin cytotoxicity in rat renal tubular cells. Nephrol Dial Transplant 2005;20:1551-1558. 